\title{
KINETICS AND EQUILIBRIUM STUDIES ON THE BIOSORPTION OF HEXAVALENT CHROMIUM FROM AQUEOUS SOLUTIONS USING BACILLUS SUBTILIS BIOMASS
}

\author{
A. SIVAPRAKASH - R. ARAVINDHAN - J. RAGHAVA RAO* - B. UNNI NAIR \\ Chemical Laboratory, Central Leather Research Institute, Adyar, Chennai- 600020 \\ (phone: +91442441 1630;fax: +91442491 1589) \\ Corresponding author \\ e-mail:rao_clri@yahoo.com \\ (Received $14^{\text {th }}$ August 2007 ; accepted $6^{\text {th }}$ July 2009)
}

\begin{abstract}
Heavy metal contamination of industrial effluents is one of the significant environmental problems due to their toxic nature and accumulation throughout the food chain as non-biodegradable pollutants. In this study, dead Bacillus subtilis biomass was assessed for its efficiency to remove chromium(VI) from aqueous solutions. Optimum $\mathrm{pH}$ and temperature for biosorption of $\mathrm{Cr}(\mathrm{VI})$ were found to be 2.0 and $30 \mathrm{oC}$, respectively. The biomass has the maximum biosorption capacity of $14.54 \mathrm{mg} / \mathrm{g}$ of biomass at $100 \mathrm{ppm}$ initial chromium concentration and $2 \mathrm{~g} / \mathrm{l}$ biomass loading. The biosorption process followed pseudo first order kinetic model, implying that the initial rate of biosorption is totally independent of the initial concentration. The biosorption of $\mathrm{Cr}(\mathrm{VI})$ is well described by Langmuir isotherm, which express the existence of monolayer adsorption under the experimental conditions. The adsorptiondesorption experiments performed inferred the reusability of the biomass. X-ray photoelectron spectroscopy studies revealed that chromium bound on to the B. subtilis biomass was in trivalent form.

Keywords: Biosorption, Bacillus subtilis, hexavalent chromium, adsorption isotherms, biomass
\end{abstract}

\section{Introduction}

Rapid industrialization has led to increased disposal of heavy metals and radionuclides into the environment. Current industrial metal effluent treatment methods posses various disadvantages such as lack of cost effectiveness, production of toxic chemical sludge, etc. Therefore the removal of toxic heavy metals to an environmentally safe level in a cost effective and environment friendly manner assumes greater importance. Biosorption, an environment friendly technology to clean up the environment based on the utilization of dead biomass can be an efficient and cost effective remedy.

Chromium is a toxic metal of widespread industrial use and exists in several oxidation states. The most stable and common forms are the trivalent $\mathrm{Cr}$ (III) and the hexavalent $\mathrm{Cr}(\mathrm{VI})$ species, which display quite different chemical properties. Chromium(VI) is designated and widely recognized to be a human inhalation carcinogen [1]. Chromium(III) is less toxic when compared to Chromium(VI) and it has low acute and chronic toxicity to humans at high doses. High doses of Chromium(VI) compounds are also associated with nephrotoxicity [2, 3]. Acute exposure to high levels of Chromium(VI) can produce nervous system damage and liver disorder [1,3].

Extensive use of chromium in electroplating, tanning, textile dyeing results in the effluents containing $\mathrm{Cr}(\mathrm{VI})$ and $\mathrm{Cr}(\mathrm{III})$ at concentrations ranging from tenths to hundreds of milligrams/litre. Several procedures have been proposed for removal of chromium(VI) from industrial wastewaters. Conventional methods for removing chromium(VI) ions from wastewater include: chemical reduction, membrane separation, electrochemical 
treatment, ion exchange and evaporative recovery. Although the effectiveness of these methods has been proved, they suffer from a major disadvantage, namely lack of cost effectiveness. Other limitations include energy intensive processing and concentration dependence, low efficiency, not feasible to reduce the chromium concentration to levels as low as required by environmental legislation and production of toxic chemical sludge, which needs additional treatment. These processes may be ineffective or extremely expensive especially when the metals in solution are in the range of $1-100 \mathrm{mg} / \mathrm{l}$ [4]. Hence many researchers worked on the biosorption of $\mathrm{Cr}(\mathrm{VI})$ using different biosorbents such as Rhizopus, dead fungal biomass of Aspergillus niger, Rhizopus oryzae, Saccharomyces cerevisiae, Ecklonia biomass, peat moss and modified saw [5-9].

Bacillus subtilis is a Gram-positive, aerobic, rod-shaped bacterium and ubiquitous in soils and waters. Its parietal structure is well known and is composed primarily of peptidoglycan and teichoic acid [10]. Peptidoglycan is a polymer of acetylglucosamine and acetylmuramic acid, which carry mainly carboxylic and hydroxyl functional groups. On the other hand, teichoic acid is a polymer of copyranosyl glycerol phosphate, which carries mostly phosphate and hydroxyl groups. B. subtilis is widely used in the commercial production of various enzymes. In this study, dead $B$. subtilis biomass has been used for the removal of hexavalent chromium. Advantages of using dead B. subtilis biomass mainly recline on the abundant availability of the source of biomass, which comes from the existing enzyme fermentation industries. Also, the use of dead cells in biosorption is most advantageous for wastewater treatment, in that, the dead organisms are not affected by toxic wastes; they do not require a continuous supply of nutrients and they can be regenerated and reused for many cycles [11]. Dead cells may also be stored or used for extended periods at room temperature without putrefaction.

\section{Materials and methods}

\section{Preparation of biomass}

Bacillus subtilis strain was obtained from Tamil Nadu Agricultural University, Coimbatore. It was grown and maintained on both nutrient broth and nutrient agar. It was cultivated at room temperature in medium containing: soluble starch-20 g/l; beef extract$10 \mathrm{~g} / \mathrm{l}$; yeast extract $-2 \mathrm{~g} / \mathrm{l}$; peptone $-5 \mathrm{~g} / \mathrm{l} ; \mathrm{NaCl}-5 \mathrm{~g} / \mathrm{l}$. (pH adjusted to 7.2). After a week of incubation at $33 \pm 1{ }^{\circ} \mathrm{C}$, biomass was harvested by means of centrifugation at 10,000 rpm for 10 minutes, washed twice with distilled water and then dried for 6 hours at $80^{\circ} \mathrm{C}$ in an air oven. The dried biomass was then crushed with a mortar and pestle to a fine powder. The powdered biomass was stored in an air tight pack and used for biosorption.

\section{Chemicals}

$\mathrm{K}_{2} \mathrm{Cr}_{2} \mathrm{O}_{7}$ used in the study was of analytical grade procured from Ranbaxy Chemicals. All other reagents used were of analytical grade, unless stated otherwise. Double distilled water has been used throughout the project work, unless stated otherwise. Chromium solution of different concentrations was prepared by suitably diluting the $1000 \mathrm{ppm}$ stock solution to known volumes. 


\section{Estimation of chromium}

Amount of chromium in a given solution was determined spectrophotometrically at $540 \mathrm{~nm}$ using 1, 5-diphenyl carbazide as the complexing agent [12]. The sample containing $\mathrm{Cr}(\mathrm{VI})$ ions was mixed with $1 \mathrm{ml}$ of $3 \mathrm{~N} \mathrm{H}_{2} \mathrm{SO}_{4}$ and $1 \mathrm{ml}$ of $0.25 \% 1$, 5diphenyl carbazide solution and made up to known volume. The absorbance at $540 \mathrm{~nm}$ was measured for the purple coloured solution after 10 minutes ageing. A calibration curve was drawn in the range of 5 to $50 \mathrm{ppm}$ by plotting absorbance against concentration of chromium.

\section{Biosorption experiments}

Batch biosorption experiments were conducted in $100 \mathrm{ml}$ Erlenmeyer flasks containing $50 \mathrm{ml}$ chromium solution. Equilibrium studies were performed using $100 \mathrm{mg}$ dried ground biomass per $50 \mathrm{ml}$ of chromium solution. The test solutions were agitated on shaker with temperature controller at a constant speed of 75 strokes per minute. Samples were taken at definite intervals $(0,10,20,30,45,60,120,180,240,300,360$, 420 and $480 \mathrm{~min}$ ), centrifuged at $10,000 \mathrm{rpm}$ for $5 \mathrm{~min}$ to remove the biomass and analyzed for residual metal ion concentrations. Chromium ions adsorbed on to the biosorbent was calculated from the difference between the metal ion concentration in the solution before and after the biosorption process.

In order to find out the effect of $\mathrm{pH}$ on the biosorption process and to find the optimum $\mathrm{pH}$, equilibrium batch experiments were carried out at various $\mathrm{pH}$ ranging from 2 to 8 by keeping all the other parameters constant. The batch biosorption experiments were also done at different temperatures $\left(25,30,35\right.$ and $\left.40{ }^{\circ} \mathrm{C}\right)$ to find the optimum temperature for biosorption. To study the effect of initial chromium concentration on the equilibrium uptake by the biomass, batch experiments were done at various initial metal ion concentrations $(50,75,100,125$ and $150 \mathrm{mg} / \mathrm{l})$. In order to find out the effect of the biomass loading on the uptake of chromium, batch experiments were done at various biomass concentrations $(1,1.5,2,2.5$ and $3 \mathrm{~g} / \mathrm{l})$.

The $\mathrm{Cr}(\mathrm{VI})$ uptake by $B$. subtilis biomass was calculated from the difference between the initial and final chromium concentration as follows,

$$
q=\frac{\left(C_{o}-C_{e}\right)}{S} V
$$

where, $\mathrm{q}$ is the $\mathrm{Cr}(\mathrm{VI})$ uptake by the biomass $(\mathrm{mg} / \mathrm{g}), \mathrm{C}_{\mathrm{o}}$ is the initial $\mathrm{Cr}(\mathrm{VI})$ concentration $(\mathrm{mg} / \mathrm{l}), \mathrm{C}_{\mathrm{e}}$ is the final $\mathrm{Cr}(\mathrm{VI})$ concentration $(\mathrm{mg} / \mathrm{l}), \mathrm{S}$ is the biosorbent dosage $(\mathrm{g})$ and $\mathrm{V}$ is the solution volume (1).

\section{Desorption experiments}

In order to determine the reusability of biosorbent consecutive adsorption-desorption cycles were repeated three times by using the same biosorbent. Desorption of $\mathrm{Cr}(\mathrm{VI})$ ions was performed by $0.1 \mathrm{M} \mathrm{NaOH}$ solution. Biomass loaded with $\mathrm{Cr}(\mathrm{VI})$ ions was placed in the desorption medium and agitated for a period of 3 hours at a constant speed of 75 strokes per minute. The final $\mathrm{Cr}(\mathrm{VI})$ concentration in the aqueous phase was determined by using a spectrophotometer. After each cycle of adsorption-desorption, biosorbent was 
washed with distilled water and reconditioned for adsorption in the succeeding cycle. The desorption ratio was calculated from the amount of metal ions adsorbed on the B. subtilis biomass and the final $\mathrm{Cr}(\mathrm{VI})$ ion concentration in the adsorption medium.

\section{XPS analysis}

The X-ray photoelectron spectroscopy (XPS) studies were carried out by a VG Microtech Multilab ESCA 3000 spectrometer with non-monochromotized MgKa X-ray source $(\mathrm{h} v=1253.6 \mathrm{eV})$. The samples were degassed for several hours in the chamber to minimize air contamination to sample surfaces.

\section{Results and discussion}

\section{Effect of pH}

$\mathrm{pH}$ is a vital parameter affecting the biosorption process. The results obtained are shown in (Fig. 1.)

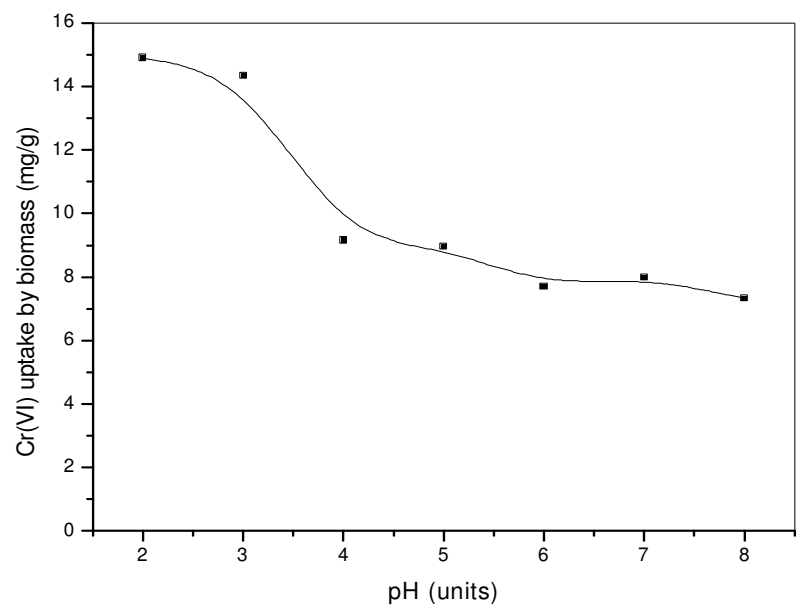

Figure 1. Effect of pH on the Cr(VI) uptake by B. subtilis: Cr(VI) conc. 100ppm, biomass concentration $=2 \mathrm{~g} / \mathrm{l}$, Temperature $=30^{\circ} \mathrm{C}$ agitation $=75$ strokes per minute.

From the figure, it is observed that the biosorption efficiency of $\mathrm{Cr}(\mathrm{VI})$ decreased as the $\mathrm{pH}$ increased. The maximum uptake capacity of the biomass was $14.9 \mathrm{mg} / \mathrm{g}$ for an initial $\mathrm{Cr}(\mathrm{VI})$ concentration of $100 \mathrm{ppm}$ at $\mathrm{pH}$ of 2.0.

The increased binding of hexavalent chromium at low $\mathrm{pH}$ can be explained by two factors. First, adsorption of $\mathrm{Cr}(\mathrm{VI})$ at $\mathrm{pH} 2.0$ suggests that the negatively charged chromium species (chromate/dichromate in the medium) bind through electrostatic attraction to positively charged functional groups on the surface of biosorbents. As the $\mathrm{pH}$ increased, the overall surface charge on the cells became negative and biosorption decreased. In alkali conditions, carboxylate group exists in deprotonated form and has net negative charge. As a result, the surface charge of the biosorbents become negative and biosorption of $\mathrm{Cr}(\mathrm{VI})$ decreases. 
Secondly, the solution chemistry of chromium(VI) ions can affect the biosorption process. Previous studies showed that chromium exhibits different types of $\mathrm{pH}$ dependent equilibria in solutions. Sorbate and chromium form stable complexes such as $\mathrm{Cr}_{2} \mathrm{O}_{7}{ }^{2-}$, $\mathrm{HCrO}_{4}{ }^{-}, \mathrm{CrO}_{4}{ }^{2-}$, and $\mathrm{HCr}_{2} \mathrm{O}_{7}{ }^{-}$, the fraction of any particular species is dependent on chromium concentration and $\mathrm{pH}$. In low chromium concentration, the main fraction is $\mathrm{HCrO}_{4}{ }^{-}$with $\mathrm{pH}$ below 5.0, whereas the $\mathrm{CrO}_{4}{ }^{2-}$ increases with increase of $\mathrm{pH}$ value and becomes the main form with $\mathrm{pH}$ above $7.0[13,14]$.

\section{Effect of temperature}

In the present study, the temperature is varied from 25 to $40^{\circ} \mathrm{C}$. With the increase of temperature from 30 to $40^{\circ} \mathrm{C}$, the uptake decreases from 28.76 to $24.32 \%$. The results obtained are illustrated in (Fig. 2.).

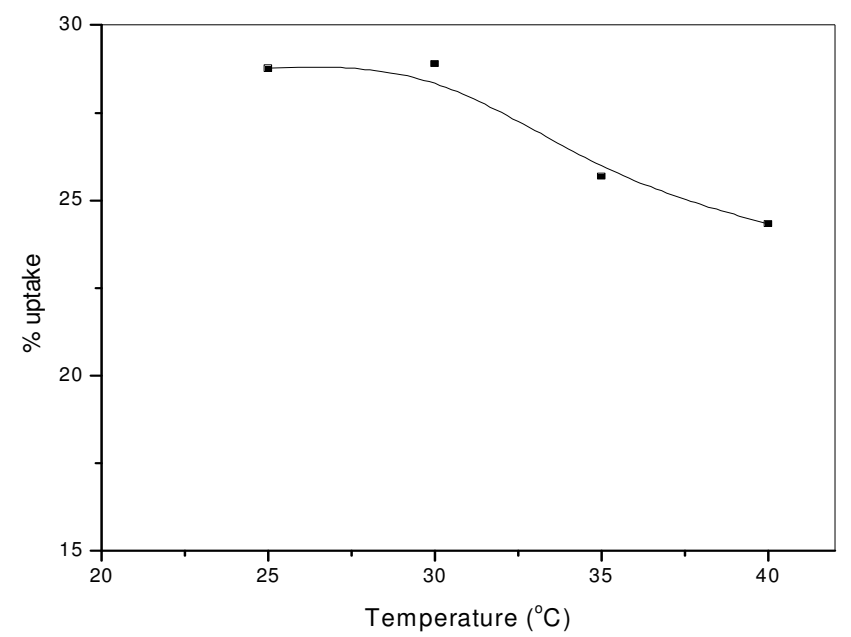

Figure 2. Temperature versus \% Cr(VI) uptake by B. subtilis: Cr(VI) conc. 100ppm, biomass concentration $=2 \mathrm{~g} / \mathrm{l}, \mathrm{pH}=2$, agitation $=75$ strokes per minute.

From the figure, it is observed that the uptake capacity is influenced by the experimental temperature conditions. The decrease of equilibrium uptake with the increase in temperature may be due to the exothermic nature of adsorption process.

\section{Effect of initial metal concentration}

$\mathrm{Cr}(\mathrm{VI})$ sorption was studied in batch experiments $(\mathrm{pH} 2.0)$ using different initial $\mathrm{Cr}(\mathrm{VI})$ concentrations of $50,75,100,125,150 \mathrm{ppm}$. The equilibrium uptake of the biomass was $12.03 \mathrm{mg} / \mathrm{g}$ (48.64\%), $13.28 \mathrm{mg} / \mathrm{g}(35.57 \%), 14.34 \mathrm{mg} / \mathrm{g}(28.88 \%)$, and $14.73 \mathrm{mg} / \mathrm{g}(23.61 \%)$ and $15.02 \mathrm{mg} / \mathrm{g}(20.10 \%)$ at initial concentration 50, 75, 100, 125 , and150 ppm chromium, respectively (Fig. 3.). 


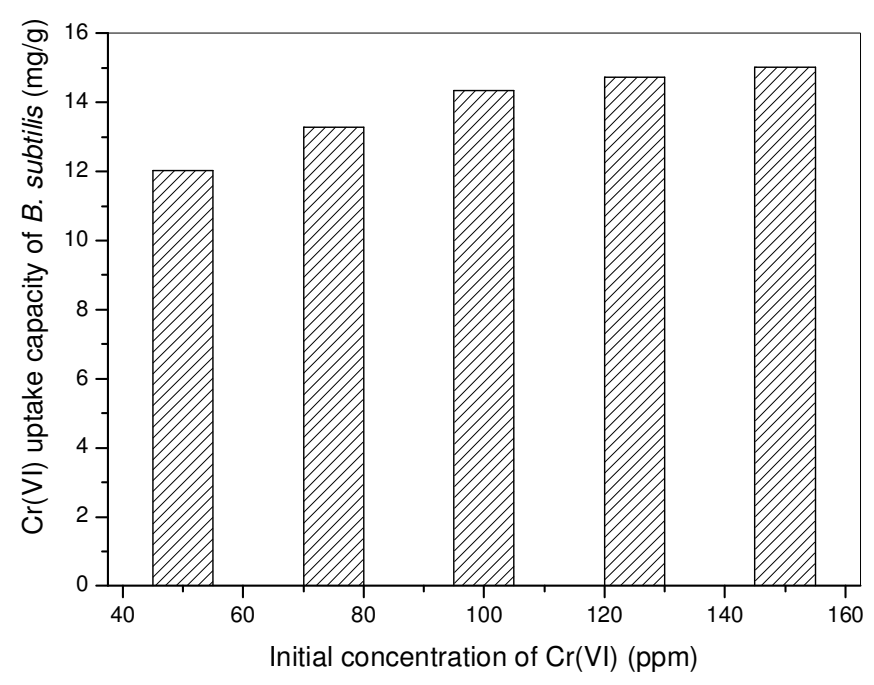

Figure 3. Effect of initial concentration of $\mathrm{Cr}(\mathrm{VI})$ on uptake capacity: biomass concentration $=2 \mathrm{~g} / \mathrm{l}, \mathrm{pH}=2$, Temperature $=30^{\circ} \mathrm{C}$, agitation $=75$ strokes per minute .

It is evident that the amount of chromium adsorbed onto the biomass increases gradually with an increasing concentrations of $\mathrm{Cr}(\mathrm{VI})$. The increase of adsorption yield with the increase in metal ion concentration is probably due to higher interaction between the metal ions and metal sequestering sites of biosorbent.

\section{Effect of biomass concentration}

The $\mathrm{Cr}(\mathrm{VI})$ uptake by the biomass decreases with the increase in biomass concentration (Fig. 4).

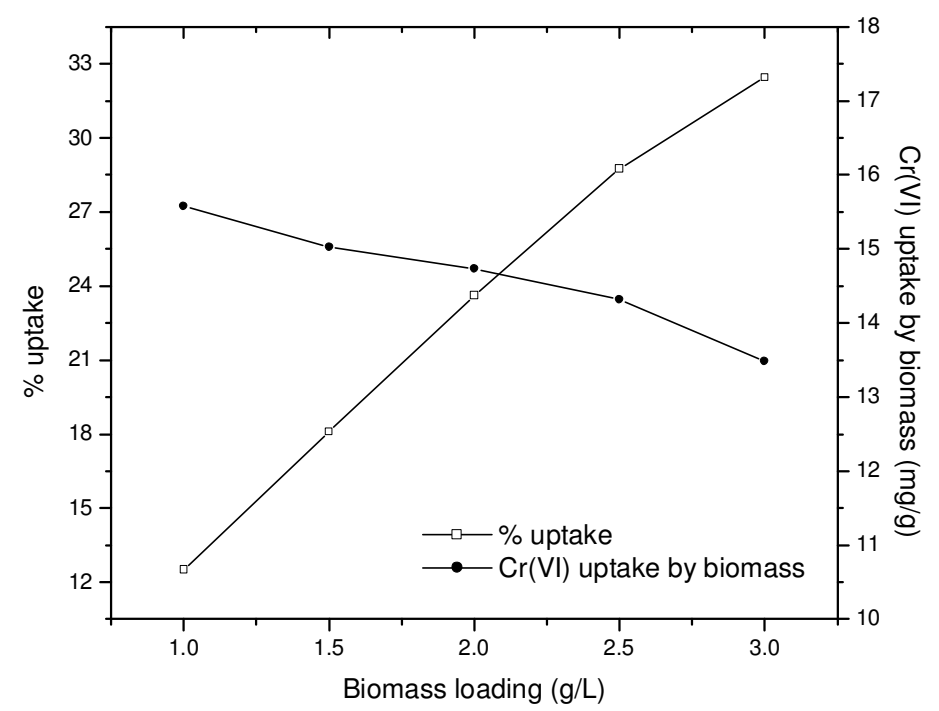

Figure 4. Effect of biomass loading on \% uptake and uptake capacity: $\mathrm{Cr}$ (VI) conc. 100ppm, $p H=2$, Temperature $=30^{\circ} \mathrm{C}$, agitation $=75$ strokes per minute.

APPLIED ECOLOGY AND ENVIRONMENTAL RESEARCH 7(1): 45-57. 
When the biomass concentration increased from 1 to $3 \mathrm{~g} / \mathrm{l}$, the adsorption capacity of biomass decreased from 15.57 to $13.48 \mathrm{mg} / \mathrm{g}$. The decrease in metal uptake by increasing the biosorbent dosage may be due to complex interactions of several factors. The important factor being at high sorbent dosages the available metal ions are insufficient to cover all the exchangeable sites on the biosorbent, usually resulting in low metal uptake. In gold biosorption by dried biomass of Azolla filiculoides, $5 \%$ decrease in gold uptake efficiency was observed when the biomass concentration was increased from $1 \mathrm{mg} / \mathrm{l}$ to 9 $\mathrm{mg} / \mathrm{l}[15]$.

\section{Biosorption kinetics}

The initial adsorption rate was rapid and thereafter adsorption was gradual and equilibrium was reached after 8 hours. Kinetic models such as pseudo first order and pseudo second order have been used to describe the kinetics of adsorption. The rate constants of chromium adsorption on biomass were determined using the pseudo first order (Lagergren rate equation) expression shown below, [16]

$$
\log \left(q_{e}-q_{t}\right)=\log q_{e}-\frac{k_{1}}{2.303} t
$$

where, $\mathrm{k}_{1}$ is the Lagergren rate constant and $\mathrm{q}_{\mathrm{e}}$ and $\mathrm{q}_{\mathrm{t}}$ are the amounts of chromium adsorbed $(\mathrm{mg} / \mathrm{g})$ at equilibrium and at time $\mathrm{t}$, respectively. The straight-line plots of $\log \left(\mathrm{q}_{\mathrm{e}}-\mathrm{q}_{\mathrm{t}}\right)$ versus $\mathrm{t}$ for different chromium concentrations indicate the applicability of the above equation to chromium biosorption on the biomass. The values of $\mathrm{k}_{1}$ and $\mathrm{R}^{2}$ along with the calculated uptake capacity at particular initial concentration are provided in (Table 1.)

Table 1. Rate constants of Cr(VI) biosorption by dead B. subtilis

\begin{tabular}{|c|c|c|c|c|c|c|c|c|c|}
\hline \multirow[b]{2}{*}{$\begin{array}{l}\text { Initial } \\
\text { conc. } \\
(\mathbf{m ~ g / g})\end{array}$} & \multirow[b]{2}{*}{$\begin{array}{l}\mathbf{q}_{\mathrm{e}(\exp )} \\
(\mathrm{mg} / \mathrm{g})\end{array}$} & \multicolumn{3}{|c|}{ First order rate constants } & \multicolumn{3}{|c|}{$\begin{array}{l}\text { Pseudo second order rate } \\
\text { constants }\end{array}$} & \multicolumn{2}{|c|}{$\begin{array}{l}\text { Intraparticle diffusion } \\
\text { rate constants }\end{array}$} \\
\hline & & $\begin{array}{l}\mathbf{k}_{1} \\
\left(\min ^{-1}\right)\end{array}$ & $\begin{array}{l}\mathbf{q}_{\mathrm{e}(\mathrm{cal})} \\
(\mathrm{mg} / \mathrm{g})\end{array}$ & $\mathbf{R}^{2}$ & $\begin{array}{l}\mathbf{k}_{2}, \\
\left(\mathbf{g m g}^{-1} \min ^{-}\right. \\
\left.{ }^{1}\right)\end{array}$ & $\begin{array}{l}\mathbf{q}_{\mathrm{e}(\mathrm{cal})} \\
(\mathrm{mg} / \mathrm{g})\end{array}$ & $\mathbf{R}^{2}$ & $\begin{array}{l}\mathrm{k}_{\mathrm{p}} \\
\left(\mathrm{mgg}^{-1} \min ^{-1 / 2}\right)\end{array}$ & $\mathbf{R}^{2}$ \\
\hline 50 & 12.04 & $4.61 \times 10^{-03}$ & 12.47 & 0.971 & $1.17 \times 10^{-04}$ & 21.42 & 0.831 & 0.64 & 0.984 \\
\hline 75 & 13.30 & $4.25 \times 10^{-03}$ & 13.55 & 0.982 & $1.01 \times 10^{-04}$ & 23.66 & 0.823 & 0.69 & 0.984 \\
\hline 100 & 14.40 & $4.12 \times 10^{-03}$ & 14.69 & 0.976 & $8.79 \times 10^{-05}$ & 26.04 & 0.796 & 0.75 & 0.982 \\
\hline 125 & 14.80 & $4.27 \times 10^{-03}$ & 15.42 & 0.973 & $7.22 \times 10^{-05}$ & 28.51 & 0.79 & 0.78 & 0.981 \\
\hline 150 & 15.20 & $4.28 \times 10^{-03}$ & 15.67 & 0.971 & $8.35 \times 10^{-05}$ & 27.56 & 0.784 & 0.80 & 0.981 \\
\hline
\end{tabular}


The kinetics of adsorption can also be described by pseudo second order equation and it is given by [17]

$$
\frac{t}{q_{t}}=\frac{1}{k_{2} q_{e}^{2}}+\frac{t}{q_{e}}
$$

where $\mathrm{k}_{2}(\mathrm{~g} / \mathrm{mg} \min )$ is the second order rate constant. The straight line plots of $\mathrm{t} / \mathrm{q}_{\mathrm{t}}$ versus $t$ for different chromium concentrations indicate the applicability of the above equation to chromium biosorption on the biomass. The second order rate constant, $\mathrm{R}^{2}$ along with the calculated uptake capacity at particular initial concentration are provided in (Table 1). From the table, it is very clear that the sorption of $\mathrm{Cr}(\mathrm{VI})$ by B. subtilis biomass follows pseudo first order kinetic model, implying that this system is totally independent of initial concentration.

Adsorption process incorporates the transport of adsorbate from bulk solution to the interior surface of the pores. In some adsorption processes this step becomes the ratecontrolling factor. Hence, the data obtained were further processed for testing the role of diffusion (as the rate controlling step) in the adsorption process. The rate parameters for intraparticle diffusion $\left(\mathrm{k}_{\mathrm{d}}\right)$ for $\mathrm{Cr}(\mathrm{VI})$ were determined by using the following equation,

$$
q_{t}=k_{d} \sqrt{t}
$$

where, $\mathrm{k}_{\mathrm{d}}$ is the rate constant of intraparticle diffusion parameter $\left(\mathrm{mgg}^{-1} \mathrm{~min}^{-1 / 2}\right)$.

According to the Weber and Moris model [18], uptake is proportional to the square root of contact time during the course of adsorption. (Fig. 5.) shows a plot of $\mathrm{q}_{\mathrm{t}}$ versus $\sqrt{\mathrm{t}}$ for the present system. It is known that if the intraparticle diffusion is the rate limiting step then the lines should pass through the origin. It can be seen from the figure that the lines didn't pass through the origin. Hence, in this case, intraparticle diffusion is not the rate-limiting step.

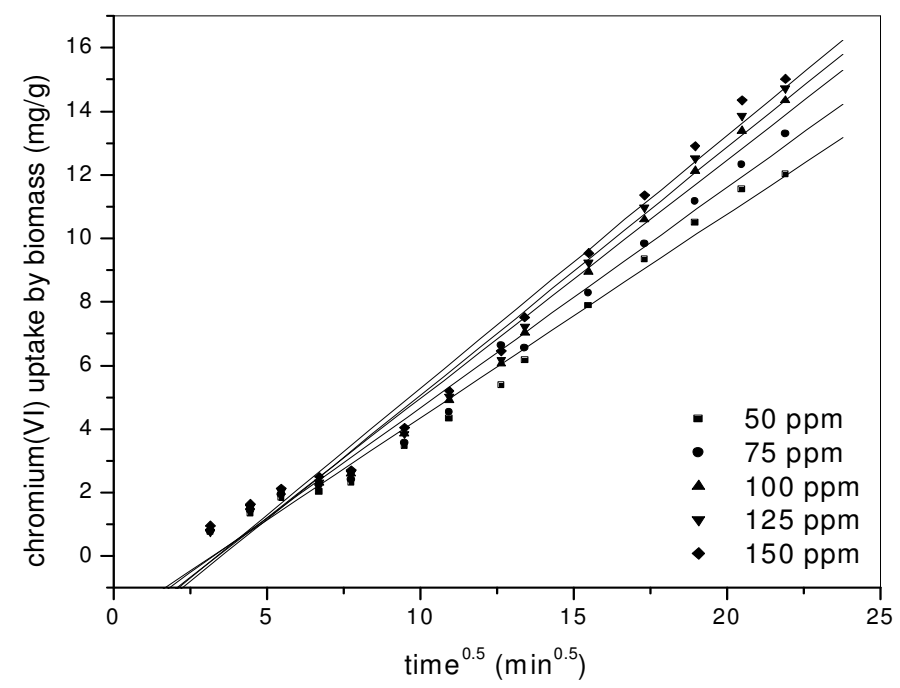

Figure 5. Intraparticle diffusion model of $\mathrm{Cr}(\mathrm{VI})$ biosorption by dead B. subtilis: $p H=2$, Temperature $=30^{\circ} \mathrm{C}$, adsorption period $=8$ hours. 


\section{Analysis of adsorption isotherms}

Adsorption isotherms were used to characterize the interaction of each chromium species with the adsorbent. This provides a relationship between the concentration of $\mathrm{Cr}(\mathrm{VI})$ in the adsorption medium and the amount of $\mathrm{Cr}(\mathrm{VI})$ adsorbed on the solid phase when the two phases are at equilibrium.

Langmuir and Freundlich adsorption isotherms are the two widely used isotherms. The Langmuir model is based on the assumption of surface homogeneity such as equally available adsorption sites, monolayer surface coverage, and no interaction between adsorbed species. This model assumes: (i) reversible adsorption (ii) no change in the properties of the adsorbed molecules (iii) no lateral interaction between adsorbed molecules (iv) one adsorption site per molecule and (v) that all adsorption sites have the same affinity for the sorbate [19]. The following represents the Langmuir isotherm equation,

$$
\frac{C_{e}}{q_{e}}=\frac{1}{Q_{o} b}+\frac{C_{e}}{Q_{o}}
$$

The Freundlich equation is the empirical relationship whereby it is assumed that the adsorption energy of a metal ion binding to a site on an adsorbent depends on whether or not the adjacent sites are already occupied. One limitation of the Freundlich model is that the amount of adsorbed solute increases indefinitely with the concentration of solute in the solution. The empirical equation takes the form [20]

$$
\log q_{e}=\log K+\frac{1}{n} \log C_{e}
$$

where $\mathrm{q}_{\mathrm{e}}$ and $\mathrm{C}_{\mathrm{e}}$ are the equilibrium adsorption capacity of the biosorbent and the equilibrium concentration in the aqueous solution, respectively. $\mathrm{K}$ and $\mathrm{n}$ are Freundlich constants related to sorption capacity and sorption intensity of adsorbents, $Q_{o}$ is the maximum sorption capacity of biomass to uptake $\mathrm{Cr}(\mathrm{VI})(\mathrm{mg} / \mathrm{g})$ and $\mathrm{b}$ is the Langmuir constant related to the energy of adsorption $(1 / \mathrm{g})$. The value of $\mathrm{n}$ falling in the range of $1-$ 10 indicates favorable sorption. The adsorption constants and correlation coefficients obtained from the Langmuir and Freundlich isotherms are provided in (Table 2.).

Table 2. Equilibrium isotherm constants of Cr(VI) biosorption by by dead B. subtilis

\begin{tabular}{ccccccc}
\hline \multirow{2}{*}{$\begin{array}{c}\text { Quantity of biomass } \\
\text { used (mg) }\end{array}$} & \multicolumn{3}{c}{ Langmuir constants } & \multicolumn{3}{c}{ Freundlich constants } \\
\cline { 2 - 7 } & $\mathbf{Q}_{\mathbf{0}}$ (mg/g) & $\mathbf{b}\left(\mathbf{L m g}^{-\mathbf{1}}\right)$ & $\mathbf{R}^{\mathbf{2}}$ & $\mathbf{K}$ & $\mathbf{1 / n}$ & $\mathbf{R}^{\mathbf{2}}$ \\
\hline 500 & 14.73 & 0.095 & 0.998 & 7.74 & 0.117 & 0.941 \\
750 & 16.26 & 0.075 & 0.990 & 7.08 & 0.151 & 0.844 \\
1000 & 16.37 & 0.103 & 0.999 & 7.52 & 0.149 & 0.976 \\
1250 & 15.97 & 0.102 & 0.999 & 6.84 & 0.165 & 0.976
\end{tabular}

$\mathrm{Cr}(\mathrm{VI})$ conc. range 50-150 ppm, biomass loading range $1-3 \mathrm{~g} / \mathrm{l}, \mathrm{pH}=2$, Temperature $=30^{\circ} \mathrm{C}$. 
It is observed from (Table 2) that the equilibrium data are well represented by Langmuir isotherm equation when compared to Freundlich equation. The sorption equilibrium data fit Langmuir and Freundlich equation with an average $\mathrm{R}^{2}$ value of 0.997 and 0.934 , respectively. The best fit of equilibrium data for Langmuir expression confirms the monolayer coverage of $\mathrm{Cr}(\mathrm{VI})$ onto $B$. subtilis biomass

\section{Separation factor, $R_{L}$}

The essential characteristics of the Langmuir isotherms can be expressed in terms of a dimensionless constant separation factor or equilibrium parameter, $\mathrm{R}_{\mathrm{L}}$, which is defined as:

$$
R_{L}=\frac{1}{1+b C_{o}}
$$

Where $b$ is the Langmuir constant and $\mathrm{C}_{\mathrm{o}}$ is the initial concentration of $\mathrm{Cr}(\mathrm{VI})$.

It is known that $\mathrm{R}_{\mathrm{L}}$ values between 0 and 1 indicate favourable adsorption [21]. The calculated $\mathrm{R}_{\mathrm{L}}$ values are represented in (Table 3).

Table 3. $R_{L}$ Values for the Adsorption of Cr(VI) onto B. subtilis biomass

\begin{tabular}{cccccc}
\hline \multirow{2}{*}{$\begin{array}{c}\text { Amount of } \\
\text { biomass }(\mathbf{g} / \mathbf{l})\end{array}$} & $\mathbf{5 0}$ & $\mathbf{7 5}$ & $\mathbf{1 0 0}$ & $\mathbf{1 2 5}$ & $\mathbf{1 5 0}$ \\
\cline { 2 - 6 } & 0.17 & 0.12 & 0.10 & 0.08 & 0.07 \\
1.00 & 0.21 & 0.15 & 0.12 & 0.10 & 0.08 \\
1.50 & 0.16 & 0.11 & 0.09 & 0.07 & 0.06 \\
2.00 & 0.16 & 0.12 & 0.09 & 0.07 & 0.06
\end{tabular}

$\mathrm{Cr}(\mathrm{VI})$ conc. range 50-150 ppm, biomass loading range $1-3 \mathrm{~g} / \mathrm{l}, \mathrm{pH}=2$, Temperature $=30^{\circ} \mathrm{C}$.

From the table, it is observed that sorption is more favorable. Also the value of $\mathrm{R}_{\mathrm{L}}$ in the range of $0-1$ at all initial chromium concentrations confirms the favorable uptake of $\mathrm{Cr}(\mathrm{VI})$ by $B$. subtilis biomass

\section{Desorption and reuse}

Desorption is a phenomenon or a process wherein some of a sorbed substance is released. The desorption of the adsorbed $\mathrm{Cr}(\mathrm{VI})$ ions from the biosorbents were studied in a batch system. The $\mathrm{Cr}(\mathrm{VI})$ ions adsorbed onto biosorbents were eluted with $0.1 \mathrm{M}$ $\mathrm{NaOH}$. More than $85 \%$ of the adsorbed $\mathrm{Cr}(\mathrm{VI})$ ions were desorbed from the biosorbents. In order to show the reusability of the biosorbent, adsorption-desorption experiments of $\mathrm{Cr}(\mathrm{VI})$ ions was repeated three times by using the same experimental conditions. The adsorption capacities for the biosorbent did not noticeably change during the repeated adsorption-desorption experiments. Hence this study confirms the reusable potential of the $B$. subtilis biomass. 


\section{Mechanism of chromium removal}

From the present study, it is clear that, bisorption is the mechanism of $\mathrm{Cr}(\mathrm{VI})$ removal from aqueous solution, where the anionic chromium species binds to positively charged groups of dead bacterial biomass. However, from literatures it is observed that both biosorption and bioreduction are involved in the removal of $\operatorname{Cr}(\mathrm{VI})$ from aqueous solution [22]. In order to determine the valance state of the bound chromium on the biomass, X-ray photoelectron spectroscopy was employed. The narrow scan of the $\mathrm{Cr}^{2} \mathrm{p}_{3 / 2}$ for $\mathrm{Cr}(\mathrm{VI})$ loaded biomass is shown in the (Fig. 6.).

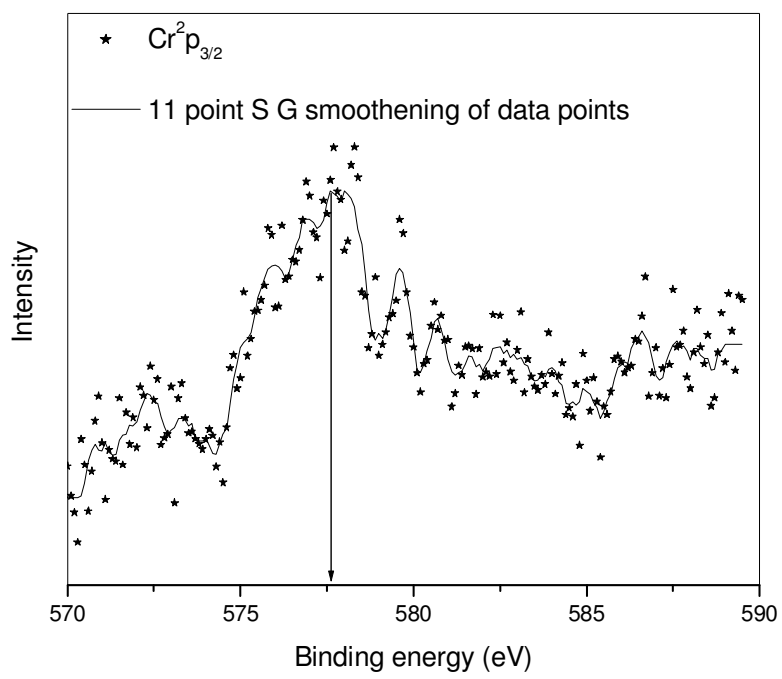

Figure 6. $\mathrm{Cr}^{2} p_{3 / 2}$ spectra of the chromium bound B. subtilis biomass after $\mathrm{Cr}(\mathrm{VI})$ biosorption

There were significant amount of chromium bound on the biomass. The bands appeared at binding energies of around 577-578 eV, which corresponds to the $\mathrm{Cr}^{2} \mathrm{P}_{3 / 2}$ orbital of $\mathrm{Cr}(\mathrm{III})$. Based on the XPS data the existence of $\mathrm{Cr}$ (III) on the biomass could be inferred. The presence of $\mathrm{Cr}(\mathrm{VI})$ is also possible, however, the quantifications was not possible due to the existence of noise peaks. Park et al., [7, 23] has established two possible mechanism for the removal of $\mathrm{Cr}(\mathrm{VI})$ from aqueous solution by dead fungal biomass. According to which, the first mechanism involves direct reduction of $\mathrm{Cr}(\mathrm{VI})$ to $\mathrm{Cr}$ (III) in the aqueous solution by contact with the biomass. The second mechanism consists of two steps: 1) the binding of $\mathrm{Cr}(\mathrm{VI})$ to positively charged groups of the biomass and 2) the reduction of $\mathrm{Cr}(\mathrm{VI})$ to $\mathrm{Cr}(\mathrm{III})$ by adjacent functional groups having lower reduction potential value than that of $\mathrm{Cr}(\mathrm{VI})$. Thus, the present study also reports the same conclusion as the earlier studies, i.e. the most of the chromium bound on the dead bacillus biomass was in $\mathrm{Cr}(\mathrm{III})$ state.

\section{Conclusions}

Biosorption of heavy metals is one of the most promising technologies involved in the removal of toxic materials from the industrials wastewater and natural waters. The biosorption process depends significantly on the $\mathrm{pH}$ of the solution and is favoured at around $\mathrm{pH}$ value of 2.0. The biosorption process is found to be exothermic in nature. The 
maximum uptake capacity of biomass for $\mathrm{Cr}(\mathrm{VI})$ increased with the increase in initial metal ion concentration and decreased with increase in biomass concentration. Biosorption obeys the pseudo first order kinetics, which implies that the rate of biosorption process is independent of initial concentration. Intraparticle diffusion is not the rate limiting step in the biosorption process. The adsorption is well described by Langmuir isotherms that expresses that monolayer adsorption exist under the experimental conditions. The adsorption-desorption experiments were successfully carried out three times. The mechanism of $\mathrm{Cr}(\mathrm{VI})$ removal by the $\mathrm{B}$. subtilis biomass was found to be adsorption-coupled reduction by employing XPS analysis. Hence, Bacillus subtilis biomass, a fermentation by-product can be used as an effective, inexpensive and alternative biosorbent for the removal of $\mathrm{Cr}(\mathrm{VI})$ from the industrial wastewaters.

Acknowledgements. Authors wish to thank Dr. C.S. Gopinath, Scientist, National Chemical Laboratory, Pune, for his help in carrying out XPS analysis. One of the authors (R.A.) is grateful to Council of Scientific and Industrial Research, Govt. of India, New Delhi for granting Senior Research Fellowship (SRF) for his Ph.D program.

\section{REFERENCES}

[1] US.EPA IRIS 'Integrated Risk Information System' (1997): A continuously updated electronic database maintained by US EPA.

[2] Paustenbach, D.J., Rinehart, W.E., Sneeham, P.J. (1991): The health hazards posed by chromium contaminated soils in residential and industrial areas: Conclusions of an expert panel. - Regulatory Toxicology and Pharmacology 13: 195-222.

[3] US EPA, 'Health effects assessment summary tables': FY - (1995).

[4] Nourbakhsh, M., Sag, Y., Ozer, D., Aksu, Z., Katsal, T., Calgar, A. (1994): A comparative study of various biosorbents for removal of chromium(VI) ions from industrial wastewater. - Process Biochemistry 29: 1-5.

[5] Niyogi, S., Abraham, E.T., Ramakrishna, S.V. (1998): Removal of Cr(VI) ions from industrial e.uents by immobilized biomass of Rhizopus arrhizus. - Journal of Science and Industrial Resarch 57: 809-816.

[6] Bai, S.R., Abraham, T.E. (2001): Biosorption of $\mathrm{Cr}(\mathrm{VI})$ from aqueous solution by Rhizopus nigricans. - Bioresource Technology 79: 73-81

[7] Park, D., Yun, Y.S., Park, J.M. (2004): Reduction of hexavalent chromium with the brown seaweed Ecklonia biomass. - Environmental Science and Technology 38: 4860-4864.

[8] Sharma, D.C., Forster, C.F. (1995): Continuous adsorption and desorption of chromium ions by Sphagnum moss peat. - Process Biochemistry 30: 293-298.

[9] Raji, C., Anirudhan, T.S. (1998): Batch Cr(VI) removal by polyacrylamide grafted saw dust: - Kinetics and thermodynamics. Water Research 32: 3772-3780.

[10] Markai, S., Andres, Y., Montavon, G., Grambow, B. (2003): Study of the interaction between europium(III) and Bacillus subtilis: Fixation sites, biosorption modeling and reversibility. - Journal of Colloid and Interface Science 262: 351-361.

[11] Gadd, G.M. (1990): Fungi and Yeasts for metal accumulation. - In: Ehrlich, C.L., Brierley, (Ed.), Microbial Mineral Recovery. McGraw Hill, New York, pp. 249-276.

[12] Vogel, A. I. (1989): Vogel's Textbook of Quantitative Chemical Analysis, 5th (Ed.) Longman Inc.: Essex.

[13] Qin, C., Du, Y., Zhang, Z., Liu, Y., Xiao, L., Shi, X. (2003): Adsorption of chromium (VI) on a novel quaternized chitosan resin. - Journal of Applied Polymer Science 90: 505-510 
[14] Arica, M.Y., Bayramoglu, G. (2005): Cr(VI) biosorption from aqueous solutions using free and immobilized biomass of Lentinus sajor-caju: Preparation and kinetic characterization. Colloids and Surfaces A. - Physicochemical Engineering Aspects 253: 203-211.

[15] Autuner, A.P.M., Watkins, G.M., Duncan, J.R. (2001): Batch studies on the removal of gold(III) from aqueous solution by Azolla filiculoides. - Biotechnology Letters 23: 249251.

[16] Namasivayam, C., Kanchana, N. (1993): Removal of congo red from aqueous solutions by waste banana pith. - Pertanika 1: 32-42.

[17] Ho, Y.S., McKay, G. (1999): Pseudo-second order model for sorption processes. - Process Biochemistry 34: 4510-465.

[18] Weber, W.J., Morris, J.C. (1963): Intraparticle diffusion during the sorption of surfactants onto activated carbon. - Journal of Sanitary Engineering Division American Society for Civil Engineers 89: 53-61.

[19] Langmuir, I. (1918): The adsorption of gases on plane surfaces of glass, mica, and platinum. - Journal of American Chemical Society 40: 1361-1368.

[20] Freundlich, H. (1906): Adsorption in solution. - Physical Chemical Society 40: 13611368.

[21] McKay, G., Blair, H.S., and Gardener, J.R. (1982): Adsorption of dyes on chitin I. Equilibrium studies. - Journal of Applied Polymer Science 27: 3043-3057.

[22] Park, D., Yun, Y.S., Jo, H.J., Park, J.M. (2005): Mechanism of hexavalent chromium removal by dead fungal biomass of Aspergillus niger. - Water Research 39: 533-540.

[23] Park, D., Yun, Y.S., Park, J.M. (2005): Use of dead fungal biomass for the detoxification of hexavalent chromium: Screening and kinetics. - Process Biochemistry 40: 2559-2565. 